\section{Progress in Oceanography}

www.elsevier.com/locate/pocean

\title{
Environmental controls on food web regimes: A fluvial perspective
}

\author{
Mary E. Power \\ Department of Integrative Biology, University of California, Berkeley, CA 94720-3140, USA
}

Available online 22 March 2006

\begin{abstract}
Because food web regimes control the biomass of primary producers (e.g., plants or algae), intermediate consumers (e.g., invertebrates), and large top predators (tuna, killer whales), they are of societal as well as academic interest. Some controls over food web regimes may be internal, but many are mediated by conditions or fluxes over large spatial scales. To understand locally observed changes in food webs, we must learn more about how environmental gradients and boundaries affect the fluxes of energy, materials, or organisms through landscapes or seascapes that influence local species interactions. Marine biologists and oceanographers have overcome formidable challenges of fieldwork on the high seas to make remarkable progress towards this goal. In river drainage networks, we have opportunities to address similar questions at smaller spatial scales, in ecosystems with clear physical structure and organization. Despite these advantages, we still have much to learn about linkages between fluxes from watershed landscapes and local food webs in river networks. Longitudinal (downstream) gradients in productivity, disturbance regimes, and habitat structure exert strong effects on the organisms and energy sources of river food webs, but their effects on species interactions are just beginning to be explored. In fluid ecosystems with less obvious physical structure, like the open ocean, discerning features that control the movement of organisms and affect food web dynamics is even more challenging. In both habitats, new sensing, tracing and mapping technologies have revealed how landscape or seascape features (e.g., watershed divides, ocean fronts or circulation cells) channel, contain or concentrate organisms, energy and materials. Field experiments and direct in situ observations of basic natural history, however, remain as vital as ever in interpreting the responses of biota to these features. We need field data that quantify the many spatial and temporal scales of functional relationships that link environments, fluxes and food web interactions to understand how they will respond to intensifying anthropogenic forcing over the coming decades.
\end{abstract}

(c) 2006 Published by Elsevier Ltd.

Keywords: Fluxes; Food web controls; Landscapes; Longitudinal gradients; Mapping; Sensing; Tracing technology; Rivers; Seascapes; Watersheds

\section{Introduction}

In fall 2004, marine scientists working in the North Pacific convened to assess the current state of understanding of dramatic changes over the last fifty years in pelagic ocean food webs, including those supporting

E-mail address: mepower@berkeley.edu. 
commercially important fish stocks. Many top predator stocks of commercial value are collapsing worldwide (Jackson et al., 2001; Pauly et al., 1998) Trawls off of South Africa that once harvested commercially valuable finfish are now engorged with jellyfish, consumers that are benefiting from the worldwide microbialization of the oceans (Jackson et al., 2001). At the base of marine food-webs, ranges of harmful and oxygen-depleting algal blooms are expanding (http://www.whoi.edu/redtide/HABdistribution/habexpand.html, Rabalais et al., 2002). Are these changes driven by population crashes or altered foraging behavior of apex predators due to overharvesting of these predators (Pauly et al., 1998; Schindler et al., 2001) or their preferred prey (Springer et al., 2003)? Are they due instead to changes in nutrients, primary producers, or zooplankton at the base of food webs? Alternatively, could changes be driven by the abundance of consumers at intermediate trophic positions that mediate energy flow from basal resources to predators, and link predators dynamically to prey, and prey of prey? Are changes in marine food webs at basal, intermediate, or apex control points in food webs responding to pressure from industrial fishing and whaling, to ocean pollution, or to climatic forcing of oceanographic regimes?

I was invited to this session as an outlier, having studied food webs in river and watershed habitats. My hosts were testing the hypothesis that there might be heuristic value in contrasting food web studies in the open ocean with studies in river drainage networks, where physical structure of the environment is more obvious. Like ecologists studying marine food webs, watershed ecologists hope some day to forecast "regime shifts" in food webs. Regime shifts in food webs change the length of important chains within more complex webs. These chains might be energy flow paths, which support predators or consumers, or functional control chains that limit abundances of potentially dominant populations (e.g., algal blooms). Predator-controlled and predator-supporting webs with long food chains can shift to webs dominated by short food chains, in which the flow of nutrients and productivity 'stall' and accumulate in 'trophic cul de sacs'. Trophic cul de sacs develop when organisms at lower food web positions curtail energy flow up food chains, either because these basal web members are well-defended against their own predators (Wootton et al., 1996), or because they alter environments so that higher trophic levels can no longer be supported (e.g., oxygen-depleting algal blooms). Regime shifts that shorten food webs often trigger societal repercussions, as do harmful algal blooms and the collapse of valuable predator populations. I was asked to discuss experimental approaches in rivers that have yielded some answers about controls over the lengths of chains that sometimes link algae through consumers to predators. Acknowledging that bottom up factors always matter (without energy and nutrients, there can be no food web), I focus here on how intermediate consumers and top predators respond to environmental factors in ways that affect the fate of primary production.

Before offering a brief personal perspective that does not begin to encompass recent progress in fluvial ecology, I list three features of river networks that can be turned to advantage in experimental and observational food web studies:

- Feasibility of direct in situ observations. In much of the drainage network, river channels are small enough to sample or survey by wading or snorkeling. Clear flowing rivers (increasingly hard to find as land use degrades streams and rivers worldwide) permit direct field observations of environments and organisms. Most of these organisms, when naive to humans, are not afraid of divers, and (in contrast to some apex predators in the open ocean (Hamner, 1995)) are not inclined to threaten or eat them.

- Extreme contrasts and steep gradients in environmental conditions that are partially predictable in space and time. Drainage networks have strong hierarchical and downstream organization (Rodriguez-Iturbe and Rinaldo, 1997). 'Downstream hydraulic geometry' (Leopold and Maddock, 1953; Leopold et al., 1964) of rivers and controls by drainage area and slope (Dietrich and Montgomery, 1998) render environmental structure, conditions, and regimes partially predictable as a function of location down the network (Vannote et al., 1980; Montgomery and Buffington, 1993; Montgomery, 1999; Power and Dietrich, 2002). At a given site, width, depth, and flow velocity change with river discharge in partially predictable ways ('at-astation hydraulic geometry', Leopold et al., 1964). As river flow rises and subsides, habitats expand and contract, habitat units are connected and disconnected, and environmental gradients change. Discharge fluctuations can deposit experimental enclosures in treetops, but also provide opportunities to study the effects on food webs of changes in density and per capita performances of web members (Power et al., 1996). 
- Replication in space and time. Watershed and river habitats delimited by natural boundaries (e.g., drainage divides, pools versus riffles, bed substrate particles) are replicated at several nested scales (Frissell et al., 1986). Each of these habitats partially delimit arenas for ecologically important interactions. The rough replication of habitat units (e.g., pools along channel reaches) can be useful for comparisons and manipulations (e.g., Power, 1984a; Power and Matthews, 1983; Power et al., 1985). Over time, discharge fluctuations of sufficient magnitude (e.g., bed scouring floods or dewatering) periodically remove organisms and reset river food webs, offering repeated opportunities to study food web assembly.

Can we use the partially predictable variation in environmental conditions along river networks to look at reassembly after floods reset communities, or to probe the effect of environment on food web controls? When or where can predators or consumers limit producer biomass and influence its composition? When or where are producers, or prey at intermediate trophic levels, likely to escape consumer control? How does environmental context affect the strength of species interactions, and their consequence for food web and ecosystem regimes? Here I review research findings from pelagic ocean and river network ecosystems that document ways in which organisms, and hence their food webs, respond to environmental heterogeneity in structures, size, and fluxes or forcings that mediate disturbance and productivity regimes. One goal is to search for natural scales that define functional effects of environmental features on key organisms and food webs in specific systems. More generally, we hope to build a broad understanding of common principles that might guide us in predicting the linkages between ecological dynamics and seascape or landscape dynamics in new systems, and under novel conditions that may arise in the future.

\section{Top down control: impacts of habitat heterogeneity and size on predation}

Increasing habitat size and complexity have long been known to weaken predator impacts on prey (Huffaker, 1958; Hastings, 1977). Evaluating this relationship in nature, however, presents a deeper challenge than it does in the laboratory or in mathematical models. What are the spatial scales that connect free-ranging predators with their prey? How mobile are predators and prey, what landscape or seascape features constrain their activities? At what natural scales do they perceive and use habitats? Do environmental discontinuities impede predators, or facilitate their foraging by concentrating prey? How should we circumscribe predator and prey populations in nature to get useful estimates of their densities and encounter rates?

\subsection{Impacts of surfaces on local predation}

Surfaces (two-dimensional boundaries) of ecological importance in the open ocean occur at large (Moore, 2003), intermediate (Wolanski and Hamner, 1988; Hamner et al., 1988; Hamner, 1995), and small (Silver et al., 1995) scales. Bacteria settle and activate metabolically on the surfaces of gelatinous zooplankton in seemingly featureless blue water pelagic habitats (Alldredge and Cohen, 1987). Fronts, the boundaries between two water masses, generate secondary currents and eddies where debris and drifting organisms accumulate. These resources are concentrated and tracked by larger fish, whales, and birds, which would otherwise starve in dilute open oceans (Wolanski and Hamner, 1988). Recently, marine biologists have used satellite tags to track the space used by large organisms (seals, whales, fishes, squid) to allow these organisms to "tell" us about chemical or physical boundaries or corridors that are difficult to detect in the open ocean (e.g., LeBoeuf et al., 1999).

Physical surfaces also focus and intensify trophic interactions in rivers. For example, wood deposited in small streams or sand-bedded rivers creates hot spots where microbes and macroinvertebrates concentrate, and retain and intensively recycle nutrients (Sedell and Maser, 1994; Benke et al., 1985). In contrast, the air-water interface is a site where aquatic insect production can be routed away from aquatic food webs to feed terrestrial consumers like spiders, lizards, bats and birds, which often aggregate around rivers to track insect emergence (Jackson and Fisher, 1986; Gray, 1989; Sabo and Power, 2002a,b; Power et al., 2004). Floating algal mats, which provide aquatic larvae with food-rich thermal incubators and partial refuges from aquatic predators (Power, 1990a), intensify this diversion of consumer production away from aquatic predators, and into the watershed. 


\subsection{Behavioral boundaries between food web regimes}

Not all boundaries are purely physical (Strayer et al., 2003). Grazing halos around refuges (from predators or physical stress) occur because organisms often forego resource acquisition to avoid stress or predation (Ogden et al., 1973; Sousa, 1985). The halo boundary marks a sharp transition from two- to three-trophic-level control over algal biomass. A similar threshold occurs along the 20 -cm depth contour in rivers of central Panama, where algae-grazing catfish remain deeper to avoid bird predation. Birds fish most commonly and effectively in water shallower than $20 \mathrm{~cm}$, where there is too little time between the surface splash and the bill strike for fish to escape. Therefore, catfish avoid shallow habitats, even during the dry season when they are most food limited (Power, 1984b), or after periods of experimental starvation (Power et al., 1989). As a result, conspicuous "bathtub rings" of algae accrue along river margins, again marking the sharp transition between three-level food chain control in the shallows, and two-level control in deeper areas where substrates are grazed clean. Similar bathtub rings occur along pool margins of Oklahoma streams with dense populations of grazing minnows (Power and Matthews, 1983).

\subsection{When is a pool a pool?}

Middle portions of river networks (drainage areas of $10-300 \mathrm{~km}^{2}$ ) are made up of meandering streams (Montgomery and Buffington, 1993) where pools alternate with faster shallower riffles flowing over bars. Riffles are habitats for small species and nurseries for young life stages, and pools accommodate larger organisms vulnerable to terrestrial or avian predators in shallow water (Power, 1987; Winfield, 1990). It is not always evident, however, whether a pocket along a heterogeneous stream profile is large enough to function as a pool. This depends on the function in question. Depths $>20 \mathrm{~cm}$ may allow pools to function as predator refuges (Power, 1984b); greater depths (e.g., $>3 \mathrm{~m}$ ) may be required for thermal stratification to provide refuges for cold-water salmonids spending the summer in rivers (Nielsen et al., 1994), or for low-flow refuge during bed scouring floods. Pool length or volume, rather than depth, may be the scale that determines whether these habitats retain or supply fluxes of insect drift, dissolved nutrients, and detritus as they spiral down river channels (Webster et al., 1975; Kovalak, 1978; Newbold et al., 1981).

Pool sizes may affect scales (within versus between habitats) at which predators and prey co-exist. Predators are usually larger (being gape limited), and therefore require deeper habitats. They are more impeded than prey from crossing shallow riffles to move between pools. In a small prairie margin stream, Brier Creek in south-central Oklahoma, pools filled with green algae were interspersed with nearly barren pools. Largemouth and spotted bass (Micropterus salmoides and M. punctatus) occurred in the green pools and their prey, grazing minnows (Campostoma anomalum) occupied the barren pools, which lacked bass (Power and Matthews, 1983). Experimentally re-arranging predatory bass and grazing minnows among pools produced the predicted release or suppression of algal biomass within five weeks. When floods rearranged bass and grazing minnows among stream pools, pool algal biomass also changed states rapidly, as predicted. In this system, bass movements between pools were restricted during periods of base (non-flood) flow by the intervening long shallow riffles. Smaller grazing minnows (when motivated by predator additions) could traverse these riffles. We found that emigration, rather than predation, accounted for about $50 \%$ of the reduction in minnow numbers following bass addition to a Campostoma pool (Power et al., 1985). This clear flowing river with its replicated pool habitats facilitated experiments that supported predictions from the trophic cascade model (Estes and Palmisano, 1974; Estes et al., 1978) and theory predicting the stabilizing effects of the differential mobility of predators versus prey through patchy environments (Huffaker, 1958; Hastings, 1977).

A different scale of co-existence occurred in one pool along Brier Creek, and throughout a larger river, the Baron Fork of the Illinois River. The only pool in Brier Creek in which bass and minnows consistently cooccurred was the largest of the twelve in our study reach. This pool had a long shallow tail that provided potential refuge for minnows from bass if bass avoided risk there from terrestrial or avian predation. This 'bigger-deeper sorting' (Power, 1987), however, did not account for bass-Campostoma co-occurrence throughout a larger river, the Baron Fork of the Illinois River. Here grazing minnows ranged freely throughout all of the pools, despite the presence of smallmouth bass, Micropterus dolomieu. Campostoma maintained dense felts of adnate cyanobacteria (Calothrix), which were overgrown with filamentous diatoms (Melosira) when minnows 
were excluded (Power et al., 1988). The failure of bass to control grazers and protect algae in this habitat may have been related to larger habitat volume, but also could have stemmed from either species differences, or a switch from a three to a four level regime of trophic control. Small mouth bass (Micropterus dolomieu) are less piscivorous than the spotted and large mouthed bass (M. salmoides, M. punctatus) of Brier Creek; their preferred alternative prey, crayfish, were abundant in the river, and possibly, bass were suppressed by their own predators - e.g., mink, gar, or anglers, all of which fished the Baron Fork and may have contributed a fourth, functionally significant, trophic level. These hypotheses of two- versus four-level control on algae remain to be tested in the Baron Fork.

In the South Fork of the Eel River in northern California, field experiments demonstrated four-level trophic control during two of five years during which fish were manipulated in large stream enclosures (Power, 1990b; Power et al., 1996). Similar experiments revealed three levels of trophic control during a third year, and two levels (fish proving functionally irrelevant to algal persistence) during the remaining two years. The length of chains controlling grazers and algae in this system varied with the attributes of intermediate consumers, which in turn were influenced by the preceding winter hydrologic regime, specifically, whether bed-scouring floods had occurred prior to the biologically active summer season. These contrasts raise the issue of the temporal scales that influence food web regimes.

\subsection{Intermediate consumers: links between producers and predators or trophic cul de sacs?}

Traits of consumers at intermediate trophic levels determine the strength of energy flow and of trophic cascades linking predators to primary producers in marine, terrestrial, and freshwater food webs (e.g., Marks et al., 2000; Bakun, this volume). What environmental factors influence traits that affect the edibility or availability of taxa dominating this intermediate trophic position? One major control is disturbance [sensu Sousa, 1984 (Traits of consumers): discrete events that kill or remove organisms and free space or resources]. Disturbance mortality generally focuses on lower trophic levels because these are less mobile, at least in benthic and terrestrial systems (Power et al., 1996). Early successional prey species or life stages (or plants or plant tissues) that appear during the first stages of recovery are generally less defended and more nutritious in terrestrial (Cates and Orians, 1975; Spiller and Agrawal, 2003), lake (Sommer, 1985) and intertidal (Sousa, 1979) ecosystems. These generalizations also apply in rivers. Attached algae in rivers are grazed by invertebrates that differ in their vulnerability to predation. Unarmored mobile grazers like mayflies and free-living midges are vulnerable to fish and invertebrate predators. Other algivores are protected from predators by a sessile life style, living under a silken retreat, often reinforced with detritus, algae or sediments (Hershey, 1987). Alternatively, mobile grazers can be defended by heavy armor, for example, armored catfish in Neotropical streams (Power, 1983), or armored caddisflies in temperate streams (Li and Gregory, 1989; Power et al., 1996). Grazers with either defense, if abundant, can be 'trophic cul de sacs', effectively truncating energy flow and top-down control to two functional levels thereby limiting attached algal biomass. Defended grazers, however, must divert resources from rapid growth and reproduction towards energetically or nutritionally expensive allocations (silk is a protein). In addition, reduced mobility (armored grazers do not drift) may decrease both postdisturbance recolonization by larvae and grazer tracking of algal 'hot spots' (but see Power, 1984a) as well as. Because allocations to defense slow growth and reduce escape from disturbance, defended grazers are more vulnerable to bed scouring floods. Edible grazers tend to dominate as communities recover from these disturbances, while armored or sessile invertebrates tend to dominate after prolonged scour free periods during drought (unless streams dry up), or downstream from dams or diversions that eliminate flood peaks (Power, 1992; Wootton et al., 1996).

In the upper mainstem of the South Fork Eel River, hydrologic disturbance influences grazer traits, which in turn determine the magnitude of algal blooms and whether top predators (juvenile salmonids and large minnows) are dynamically connected to the dominant alga in river food webs, the filamentous green Cladophora glomerata. In this Mediterranean climate, rainy winters precede the biologically active summer low-flow season, with year-to-year variation in the magnitude of winter floods. Over 15 years of observation, large algal blooms tended to follow bed scouring floods during the previous winter. In the three experiments that followed winter floods, juvenile steelhead (Oncorhynchus mykiss) and omnivorous roach Lavinia (Hesperoleucas symmetricus) suppressed insects at lower trophic levels and affected persistence of algae. Fish effects on algae 
were positive or negative, depending on whether key algivorous invertebrates during a given year were more vulnerable to fish or to invertebrate predators, which fish always suppressed. During drought years, when flows were not large enough to mobilize the river bed, Cladophora blooms would begin as usual in late May, but were quickly grazed back by herds of the large armored caddisfly, Dicosmoecus gilvipes, which were 1-2 orders of magnitude more abundant during droughts (Wootton et al., 1996). During both drought-year experiments, fish had no, or slight, influence on algal standing crops, which were released when Dicosmoecus were experimentally removed (Wootton et al., 1996).

Food web theory, developed without temporal or spatial context, predicts that disturbance should shorten food chains (Pimm and Lawton, 1977), and that increased productivity should lengthen food chains (Jenkins et al., 1992), based on the inefficiency of energy transfer. If environmental productivity accelerates succession (i.e., the recovery of invulnerable prey populations), however, it might effectively shorten food chains. We have tentative evidence of this from surveys of succession in a dark stream and a sunny stream after winter scour, in which sessile grazers dominated in the sunny stream a month earlier than in the dark stream (Power, 1992). More experimental work is needed to test the interplay of disturbance, productivity and succession in mediating trophic controls in food webs. In general, we might expect a domed relationship between food chain length and time-since-disturbance, paralleling the species richness maximum often observed at intermediate disturbance frequencies (Connell, 1978). If producers recover (or colonize) first following disturbance, they may represent the sole functionally important trophic level, and enjoy a window of time when resources are abundant and consumers are scarce (due to flood mortality as well as dilution by large river volume). As early successional prey colonize and are discovered by highly mobile predators (which may move in to search for more edible prey in more recently disturbed habitats), food chains would lengthen. As grazers or predators deplete edible plants or prey, food chains may shorten later in succession (Power et al., 1996). The time scales of these changes in the vulnerability to predators of producers or intermediate consumers are set by the recolonization dynamics of predator-resistant taxa at lower trophic positions, which in turn depends on the spatial locations of their refuges, their dispersal, and their developmental rates under given environmental conditions.

\subsection{Towards a compendium of natural scales that link landscapes or seascapes to changes in food web regimes}

To understand, and eventually forecast regime change in food webs, we must compile a quantitative understanding of the scales that link environments to local food web dynamics (Power and Rainey, 2000) and regional fluxes (Polis et al., 1997). The vignettes above illustrate examples of spatial and temporal scales of environmental features (pool depth, flood frequency) that affect performances of organisms, and therefore mediate food web regimes in rivers. Different biology, or different environmental conditions could change the scales of linkages between habitat, organisms, and food webs. For example, turbidity or surface rippling might reduce the depth at which fish are at risk from bird predation (Winfield, 1990). Warmer stream temperatures, by accelerating invertebrate life histories (Hogg et al., 1995), might increase the frequency of floods needed to maintain food webs in early successional states with grazers that are vulnerable to predators. For populations with ecologically important size structure (most organisms except for birds and mammals that have prolonged parental care), individuals will require completely different environments and resources and exert different impacts on food webs during their ontogenies (Werner and Gilliam, 1984; Greene and Beechie, 2004). Clearly, much empirical work is needed to document the scales of specific interactions. Eventually, we may begin to ascertain the more general functional scaling relationships that relate environmental heterogeneity and fluctuation, complex life histories, and food web interactions among species responding to different but partially overlapping environments in different ways. Given the size of this task, it is crucial that we prioritize and focus on the functional relationships that will be most important in determining the future of the population, resource, or environmental trajectory of interest. We may be guided by complex, holistic models, but only if we use them to motivate and focus fieldwork. Models that link dynamic environmental parameters to food web dynamics (Power et al., 1995) or to multi-stage population dynamics (e.g., Beechie et al., 2003) generally have too many parameters to calibrate or validate. Sensitivity analyses of such models, however, can guide our choice of functional relationships to give priority for field study. 
River networks, with their striking yet partially predictable longitudinal variation in energy sources, productivity, disturbance regimes, and habitat structure, seem particularly promising arenas for probing the influence of environmental conditions on food web interactions. Despite the formidable challenges of observation, experiment, and monitoring on the high seas, remarkable progress has been made by scientists working in pelagic ocean environments in quantifying the scales of these controls. In both environments, however, we remain unable to explain, let alone forecast, most food web regime changes. In watersheds, we have little quantitative knowledge about the sources and flow paths for carbon or limiting nutrients, and the processes that determine how much of this flux is retained and converted to producer, consumer, or predator biomass in channels or watersheds, versus exported downstream. In the open ocean, populations of top predators are collapsing, harmful algal blooms are increasing, and the reasons often remain obscure and controversial. Blooms of algae larger than California have been observed every several years since 1997 in the nutrient poor subtropical gyre of North Pacific, yet the drivers of this bloom remain mysterious (Wilson, 2003). We are becoming aware of these phenomena because of the increasingly available new high resolution mapping, sensing, and tracing technologies (Hershey et al., 1993; Power et al., 2005), some pioneered in the open ocean (e.g., Costa, 1998; Burgess et al., 1998; Bishop et al., 2004). Experimental enclosures or exclosures, which have been so informative in intertidal, freshwater, and terrestrial systems (Paine, 1994), are less feasible in the open ocean. As an alternative, tracers and remote sensing have been used to make powerful inferences about the spatial and temporal scales of food web responses to experimental perturbations such iron enrichment in these more open environments. These tools should speed our progress in unraveling the interplay between environmental controls, local species interactions and energy or material fluxes to different web members. I thank the conference organizers for reviewing the progress of marine scientists towards this goal, and for the stimulating opportunity to ponder this quest in ecosystems with solid versus fluid edges and vastly different process scales.

\section{Acknowledgements}

Many thanks to Wendy Palen, Blake Suttle, and Mike Limm for helpful comments on the manuscript, to Bill Dietrich for my view of riverscapes, and the National Center for Earth Surface Dynamics and the National Science Foundation for financial support.

\section{References}

Alldredge, A.L., Cohen, Y., 1987. Can microscale chemical patches persist in the sea. Microelectrode study of marine snow, fecal pellets. Science 235, 689-691.

Beechie, T.J., Steel, E.A., Roni, P., Quimby, E. (Eds.), 2003. Ecosystem Recovery Planning for Listed Salmon. NOAA Technical Memorandum NMFS-NWFSC-58, Seattle, WA.

Benke, A.C., Henry, R.L.I., Gillespie, D.M., Hunter, R.J., 1985. Importance of snag habitat for animal production in southeastern streams. Fisheries 10, 8-13.

Bishop, J.K.B., Wood, T.J., Davis, R.E., Sherman, J.T., 2004. Robotic observations of enhanced carbon biomass and export at $55^{\circ} \mathrm{S}$ during SOFeX. Science 304, 417-420.

Burgess, W., Tyack, P., Le Boeuf, B.J., Costa, D.P., 1998. An intelligent acoustic recording tag first results from free-ranging northern elephant seals. Deep Sea Research II 45, 1327-1351.

Cates, R.G., Orians, G.H., 1975. Successional status \& the palatability of plants to generalized herbivores. Ecology 56, 410-418.

Connell, J.G., 1978. Diversity in tropical rain forests and coral reefs. Science 199, 1302-1310.

Costa, D.P., 1998. The ATOC consortium. Ocean climate change: comparison of acoustic thermography, satellite altimetry and modeling. Science 281, 1327-1332.

Dietrich, W.E., Montgomery, D.R., 1998. Hillslopes, channels and landscape scale. In: Sposito, G. (Ed.), Scale Dependence and Scale Invariance in Hydrology. Cambridge University Press, Cambridge, UK, pp. 30-60.

Estes, J.A., Palmisano, J.F., 1974. Sea otters, their role in structuring nearshore communities. Science 185, $1058-1060$.

Estes, J.A., Smith, N.S., Palmisano, J.F., 1978. Sea otter predation \& community organization in the Western Aleutian Islands, Alaska. Ecology 59, 822-833.

Frissell, C.A., Liss, W.J., Warren, C.E., Hurley, M.D., 1986. A hierarchical framework for stream habitat classification, viewing streams in a watershed context. Environmental Management 10, 199-214.

Gray, L.J., 1989. Emergence production and export of aquatic insects from a tallgrass prairie stream. Southwestern Naturalist 34, 313318.

Greene, C.M., Beechie, T.J., 2004. Consequences of potential density-dependent mechanisms on recovery of ocean-type chinook salmon (Oncorhynchus tshawytscha). Canadian Journal of Fisheries and Aquatic Sciences 61, 590-602. 
Hamner, W.M., 1995. Predation, cover, and convergent evolution in epipelagic oceans. Marine and Freshwater Behavioral Physiology 26, 71-89.

Hamner, W.M., Jones, M.S., Carleton, J.H., Hauri, I.R., Williams, D.M., 1988. Zooplankton, planktivorous fish and water currents on a windward reef face: Great Barrier Reef, Australia. Bulletin of Marine Science 42, 459-479.

Hastings, A., 1977. Spatial heterogeneity \& the stability of predator-prey systems. Theoretical Population Biology $12,37-48$.

Hershey, A.E., 1987. Tubes and foraging behavior in larval Chironomidae: implications for predator avoidance. Oecologia 73, 236-241.

Hershey, A.E., Pastor, J., Peterson, B.J., Kling, G.W., 1993. Stable isotopes resolve the drift paradox for Baetis mayflies in an arctic river. Ecology 74, 2315-2325.

Hogg, I.D., Williams, D.D., Eadie, J.M., Butt, S.A., 1995. The consequences of global warming for stream invertebrates: A field simulation. Journal of Thermal Biology 20, 199-206.

Huffaker, C.B., 1958. Experimental studies on predation, dispersion factors and predator-prey oscillations. Hilgardia $27,343-383$.

Jackson, J.K., Fisher, S.G., 1986. Secondary production, emergence, and export of aquatic insects of a Sonoran desert stream. Ecology 67 , 629-638.

Jackson, J.B.C., Kirby, M.X., Berger, W.H., Bjorndal, K., Botsford, L.W., Bourque, B.J., Bradbury, R.H., Cooke, R., Erlandson, J., Estes, J.A., Hughes, T.P., Kidwell, S., Lange, C.B., Lenihan, H.S., Pandolfi, J.M., Peterson, C.H., Steneck, R.S., Tegner, M.J., Warner, R.R., 2001. Historical overfishing and the recent collapse of coastal ecosystems. Science 293, 629-638.

Jenkins, B., Kitching, R.L., Pimm, S.L., 1992. Productivity, disturbance \& food web structure at a local spatial scale in experimental container habitats. Oikos 65, 249-255.

Kovalak, W.P., 1978. Effects of a pool on stream invertebrate drift. American Midlland Naturalist 99, $119-127$.

LeBoeuf, B.J., Crocker, D.E., Costa, D.P., Blackwell, S.B., Webb, P.M., Houser, D.S., 1999. Foraging ecology of northern elephant seals. Ecolological Monographs 70, 353-382.

Leopold, L.B., Maddock III., T., 1953. The hydraulic geometry of stream channels and some physiographic implications. USGS Prof. Paper 252, Washington, DC.

Leopold, L.B., Wolman, M.G., Miller, J.P., 1964. Fluvial Processes in Geomorphology. Freeman, San Francisco.

Li, J.L., Gregory, S.V., 1989. Behavioral changes in the herbivorous caddisfly Dicosmoecus gilvipes (Limnephilidae). Journal of the North American. Benthological Society 8, 250-259.

Marks, J.C., Power, M.E., Parker, M.S., 2000. Flood disturbance, algal productivity, \& interannual variation in food chain length. Oikos 90, 20-27.

Montgomery, D.R., 1999. Process domains and the river continuum. Journal of the American Water Resources Association 35, 397-410.

Montgomery, D.R., Buffington, J.M., 1993. Channel classification, prediction of channel response, \& assessment of channel condition. Washington Dept. of Natural Resources Rep. TFW-SH10-93-002, Olympia, WA.

Moore, C., 2003. Trashed. Across the Pacific Ocean, plastics, plastics, everywhere. Natural History Magazine Nov. 2003.

Newbold, J.D., Elwood, J.W., O’Neill, R.V., van Winkle, W., 1981. Measuring nutrient spiralling in streams. Canadian Journal of Fisheries and Aquatic Sciences 38, 860-863.

Nielsen, J.L., Lisle, T.E., Ozaki, V., 1994. Thermally stratified pools and their use by steelhead in northern California streams. Transactions of the American Fisheries Society 123, 613-626.

Ogden, J.C., Brown, R., Salesky, N., 1973. Grazing by the echinoid Diadema antillarum Philippi, formation of halos around West Indian patch reefs. Science 182, 715-717.

Paine, R.T., 1994. Marine Rocky Shores and Community Ecology: An Experimentalist's Perspective. Ecology Institute, Oldendorf/Luhe, Germany.

Pauly, D., Christensen, V., Dalsgaard, J., Froese, R., Torres Jr., F., 1998. Fishing down marine food webs. Science 270, 860-863.

Pimm, S.L., Lawton, J.H., 1977. The numbers of trophic levels in ecological communities. Nature 268, 329-331.

Polis, G.A., Anderson, W.B., Holt, R.D., 1997. Toward an integration of landscape and food web ecology, The dynamics of spatially subsidized food webs. Annual Review of Ecology and Systematics 28, 289-316.

Power, M.E., 1983. Grazing responses of tropical freshwater fishes to different scales of variation in their food. Environmental Biology of Fishes 9, 103-115.

Power, M.E., 1984a. Habitat quality and the distribution of algae-grazing catfish in a Panamanian stream. Journal of Animal Ecology 53, 357-374.

Power, M.E., 1984b. Depth distributions of armored catfish, predator-induced resource avoidance? Ecology 65, 523-528.

Power, M.E., 1987. Predator avoidance by grazing fishes in temperate \& [in original?\} tropical streams, importance of stream depth and prey size. In: Kerfoot, W.C., Sih, A. (Eds.), Predation, Direct and Indirect Impacts on Aquatic Communities. University Press of New England, Hanover, NH, pp. 333-351.

Power, M.E., 1990a. Benthic turfs versus floating mats of algae in river food webs. Oikos 58, 67-79.

Power, M.E., 1990b. Effects of fish in river food webs. Science 250, 411-415.

Power, M.E., 1992. Hydrologic and trophic controls of seasonal algal blooms in northern California rivers. Archivs fur Hydrobiologie 125, 385-410.

Power, M.E., Dietrich, W.E., 2002. Food webs in river networks. Ecological Research 17, 451-471.

Power, M.E., Matthews, W.J., 1983. Algae-grazing minnows (Campostoma anomalum), piscivorous bass (Micropterus spp.) and the distribution of attached algae in a prairie-margin stream. Oecologia 60, 328-332.

Power, M.E., Rainey, W.E., 2000. Food webs and resource sheds, towards spatially delimiting trophic interactions. In: Hutchings, M.J., John, E.A., Stewart, A.J.A. (Eds.), Ecological Consequences of Habitat Heterogeneity. Blackwell Scientific, Oxford, UK, pp. 291314. 
Power, M.E., Matthews, W.J., Stewart, A.J., 1985. Grazing minnows, piscivorous bass and stream algae, dynamics of a strong interaction. Ecology 66, 1448-1456.

Power, M.E., Stewart, A.J., Matthews, W.J., 1988. Grazer control of algae in an Ozark Mountain stream [USA], effects of short-term exclusion. Ecology 69, 1894-1898.

Power, M.E., Dudley, T.L., Cooper, S.D., 1989. Grazing catfish, fishing birds, \& attached algae in a Panamanian stream. Environmental Biology of Fishes 26, 285-294.

Power, M.E., Sun, A., Parker, G., Dietrich, W.E., Wootton, J.T., 1995. Hydraulic food-chain models, an approach to the study of foodweb dynamics in large rivers. BioScience 45, 159-167.

Power, M.E., Parker, M.S., Wootton, J.T., 1996. Disturbance and food chain length in rivers. In: Polis, G.A., Winemiller, K.O. (Eds.), Food Webs, Integration of Patterns \& Dynamics. Chapman and Hall, New York, pp. 286-297.

Power, M.E., Rainey, W.E., Parker, M.S., Sabo, J.L., Smyth, A., Khandwala, S., Finlay, J.C., McNeely, F.C., Marsee, K., Anderson, C., 2004. River to watershed subsidies in an old-growth conifer forest. In: Polis, G.A., Power, M.E., Huxel, G. (Eds.), Food Webs and Landscapes. University of Chicago Press, Chicago, pp. 217-240.

Power, M.E., Brozovic, N., Bode, C., Zilberman, D., 2005. Spatially explicit tools for understanding and sustaining inland water ecosystems. Frontiers in Ecology and the Environment 3, 47-55.

Rabalais, N.N., Turner, R.E., Wiseman, W.J., 2002. Gulf of Mexico hypoxia, aka "The dead zone". Annual Review of Ecology and Systematics 33, 235-263.

Rodriguez-Iturbe, I., Rinaldo, A., 1997. Fractal River Basins: Chance and Self-organization. Cambridge University Press, New York.

Sabo, J.L., Power, M.E., 2002a. River-watershed exchange, effects of riverine subsidies on riparian lizards and their terrestrial prey. Ecology 83, 1860-1869.

Sabo, J.L., Power, M.E., 2002b. Numerical response of riparian lizards to aquatic insects \& the short-term consequences for alternate terrestrial prey. Ecology 83, 3023-3236.

Schindler, D.E., Essington, T.E., Kitchell, J.F., Boggs, C., Hilborn, R., Barabasi, A.N., 2001. Sharks and tunas, fisheries impacts on predators with contrasting life histories. Ecological Applications 12, 735-748.

Sedell, J., Maser, C., 1994. From the Forest to the Sea, the Ecology of Wood in Streams, Rivers, Estuaries, and Oceans. St. Lucie Press, Delray Beach, FL.

Silver, M.W., Coale, S.L., Steinberg, D.K., Pilskaln, C.H., 1995. Marine snow, what it is and how it affects ecosystem functioning. In: Jones, C.G., Lawton, J.H. (Eds.), Linking Species and Ecosystems. Chapman and Hall, New York, pp. 45-51.

Sommer, U., 1985. Seasonal succession of phytoplankton in Lake Constance. BioScience 35, 351-357.

Sousa, W.P., 1979. Experimental investigations of disturbance and ecological succession in a rocky intertidal algal community. Ecological Monographs 49, 227-254.

Sousa, W.P., 1984. The role of disturbance in natural communities. Annual Review of Ecology and Systematic 15, 353-391.

Sousa, W.P., 1985. Disturbance and patch dynamics on rocky intertidal shores. In: Pickett, S.T.A., White, P.S. (Eds.), The Ecology of Natural Disturbance and Patch Dynamics. Academic Press, New York, pp. 101-124.

Spiller, D.A., Agrawal, A.A., 2003. Intense disturbance enhance plant susceptibility to herbivory, natural \& experimental evidence. Ecology 84, 890-897.

Springer, A.M., Estes, J.A., van Vliet, G.B., Williams, T.M., Doak, D.F., Danner, E.M., et al., 2003. Sequential megafaunal collapse in the North Pacific Ocean, an ongoing legacy of industrial whaling? Proceedings of the National Academy of Science 100, $12223-12228$.

Strayer, D.L., Power, M.E., Fagan, W.F., Pickett, S.T.A., Belnap, J., 2003. A classification of ecological boundaries. BioScience 53, 723729.

Vannote, R.L., Minshall, G.W., Cummins, K.W., Sedell, J.R., Cushing, C.E., 1980. The river continuum concept. Canadian Journal of Fisheries and Aquatic Sciences 37, 130-137.

Webster, J.R., Waide, J.B., Patten, B.C., 1975. Nutrient cycling \& stability of ecosystems. In: Howell, F.G., Gentry, J.B., Smith, M.H. (Eds.), Mineral Cycling in Southeastern Ecosystems. Energy Research and Development Administration Symposium Series (CONF740513), Washington, DC, pp. 1-27.

Werner, E.E., Gilliam, J.F., 1984. The ontogenetic niche \& species interactions in size structured populations. Annual Review of Ecology and Systematics 15, 393-425.

Wilson, C.J., 2003. Late summer chlorophyll blooms in the oligotrophic North Pacific subtropical gyre. Geophysical Research Letters 30, OCE 4-1-OCE 4-4.

Winfield, I.J., 1990. Predation pressure from above, observations on the activities of piscivorous birds at a shallow eutrophic lake. Hydrobiologia 191, 223-231.

Wolanski, E., Hamner, W.M., 1988. Topographically controlled fronts in the ocean and their biological influence. Science 241, 177-181.

Wootton, J.T., Parker, M.S., Power, M.E., 1996. Effects of disturbance on river food webs. Science 273, 1558-1560. 